\title{
Factors Affecting the Sticking of Fine Iron Ores during Fluidized Bed Reduction
}

\author{
Shoji HAYASHI and Yoshiaki IGUCHI
}

Department of Materials Science and Engineering, Nagoya Institute of Technology, Gokiso-cho, Showa-ku, Nagoya, Aichiken, 466 Japan.

(Received on February 21, 1992; accepted in final form on June 19, 1992)

\begin{abstract}
Seven types of iron ores were reduced to iron phase in a laboratory fluidized bed at $900^{\circ} \mathrm{C}$ by $\mathrm{N}_{2}-\mathrm{H}_{2}$ mixtures to examine the influence of ore type, reducing potential, and sulfur potential on sticking phenomenon and iron morphology in the bed.

In case without $\mathrm{H}_{2} \mathrm{~S}$ addition, five types of ores having low $\mathrm{Al}_{2} \mathrm{O}_{3}$ content sticked by mostly short iron whiskers and/or porous irons, while two types of ores having high $\mathrm{Al}_{2} \mathrm{O}_{3}$ content fluidized with plain irons on their surface. Increment of the reducing potential did not much change these microstructures besides reaching to higher reduction levels. Addition of $\mathrm{H}_{2} \mathrm{~S}$ capable of forming FeS into the gas mixtures facilitated the appearance of coarse porous irons to keep fluidized until nearly complete reduction.

The overall metallization process of an ore bed was estimated to proceed under the hydrogen gas supplying control with a high gas utilization.

On the basis of the results obtained for 19 types of ores, including those employed in the previous tests, the sticking tendency is generalized in relation with factors such as iron morphology, surface energy of iron, and external shape of ore.
\end{abstract}

KEY WORDS: iron ores; fluidized bed reduction; fluidization; sticking; iron morphology; ore kind dependence; reducing potential; sulfur potential.

\section{Introduction}

Industrial utilization of a fluidized bed reduction in direct ironmaking ${ }^{1,2)}$ can not be currently found except such as FIOR and HIB processes. This is generally considered to be mainly attributed to the most serious problem of defluidization, making continuous operation impossible, which results from sticking among individual ore particles.

The sticking has some features to occur mostly during metallization of ore, sometimes accompanied with fibrous irons, and to depend strongly on the kind of iron ores. ${ }^{3-8)}$ Earlier workers ${ }^{9)}$ also reported that the sticking tends to be preferred at such conditions as high temperature, small particle of ore, and low gas velocity. These three conditions are likely to correspond indirectly to the parameters affecting the stickiness of ore particles defined by Langston and Stephens. ${ }^{10)}$ They claimed that the stickiness is directly proportional to adhesive force and contact area among ore fines, and inversely proportional to their momentum.

A number of methods to prevent defluidization were devised. As for lowering adhesive force or contact area among ore fines, once making non fibrous irons in lower temperatures, ${ }^{11)}$ diluting a bed with ores having good fluidizability, ${ }^{6)}$ coating carbon or gangues on ore surface, ${ }^{12-14)}$ mixing coke in a bed, ${ }^{6)}$ and so forth were tried. As for enhancing momentum of ores, the circulating fluidized bed with a high gas velocity is under development, ${ }^{5,15,16)}$ which is recently focused as a prereduction unit of the smelting reduction processes. ${ }^{17,18)}$ However, further researches will be necessary to understand comprehensive sticking mechanism during metallization.

Under above circumstance, we had studied reduction swelling of iron oxides pellets prepared from reagents. It was found that the abnormal swelling occurs with formation of iron whiskers in the range of $0.01-1$ as the sulfur activity in gas phase relative to $\mathrm{Fe} / \mathrm{FeS}$ equilibrium $\left(a_{s}\right)$ and reaches to the maximum at $900^{\circ} \mathrm{C}$ around $a_{s}=0.1 .^{19-21)}$ In industrial ironmaking processes, significant amounts of sulfur exist in gas phase, derived from reductants rather than ore itself, so that it is important to investigate the influence of gaseous sulfur on the reduction behavior.

Based on these findings, we had reduced 15 kinds of iron ores in either $\mathrm{CO}-\mathrm{CO}_{2}{ }^{7)}$ or $\mathrm{N}_{2}-\mathrm{H}_{2}$ mixtures ${ }^{8)}$ at around $900^{\circ} \mathrm{C}$ under a fluidized state to elucidate the relation between sticking behavior of numerous ores and sulfur potentials. The sticking was predominated with appearance of mostly fibrous irons, dependent upon the reducing temperature, the sulfur activity in gas phase originated from each ore, and the kind of reducing gas. These results coincided with our above fundamental 
Table 1. Chemical composition of iron ores. (wt \%)

\begin{tabular}{|c|c|c|c|c|c|c|c|c|c|c|c|}
\hline Name & Mark & T. $\mathrm{Fe}^{*}$ & $\mathrm{FeO}^{*}$ & $\mathrm{SiO}_{2}{ }^{*}$ & $\mathrm{Al}_{2} \mathrm{O}_{3} *$ & $\mathrm{CaO}^{*}$ & $\mathrm{MgO}^{*}$ & $\mathrm{~S}^{* *}$ & $\mathrm{Na}_{2} \mathrm{O}^{* *}$ & $\mathrm{~K}_{2} \mathrm{O}^{* *}$ & $\begin{array}{c}\text { Main mineral } \\
\text { phases }\end{array}$ \\
\hline Brazil & A & 65.20 & 0.20 & 4.29 & 1.32 & - & 0.14 & 0.0034 & 0.005 & 0.003 & $\mathrm{H}$ \\
\hline Swaziland & $\mathrm{B}$ & 63.65 & 0.18 & 4.68 & 2.15 & - & - & 0.0058 & 0.018 & 0.019 & $\mathrm{H}$ \\
\hline Hamersley & $\mathrm{C}$ & 62.10 & 0.22 & 4.45 & 2.56 & 0.22 & - & 0.0164 & 0.018 & 0.012 & $\mathrm{H}$ \\
\hline Portlady & $\mathrm{D}$ & 61.19 & 0.20 & 1.63 & 3.30 & - & 0.10 & 0.0253 & 0.009 & 0.010 & $\mathrm{H}, \mathrm{G}$ \\
\hline Goldsworthy & $\mathrm{E}$ & 65.85 & 0.08 & 3.30 & 1.25 & 0.10 & - & 0.0200 & 0.028 & 0.010 & $\mathrm{H}$ \\
\hline Krivoy-Rog & $\mathrm{G}$ & 58.52 & 3.15 & 15.62 & 1.04 & 0.30 & 0.18 & 0.0110 & 0.013 & 0.016 & $\mathrm{H}, \mathrm{Q}$ \\
\hline Santafe & $\mathrm{H}$ & 63.29 & 14.29 & 4.98 & 0.97 & 1.50 & 1.10 & 0.1183 & 0.029 & 0.030 & $\mathrm{M}, \mathrm{H}$ \\
\hline Marcona & I & 63.22 & 15.29 & 5.08 & 0.82 & 1.08 & 1.76 & 1.441 & 0.063 & $0.05 \mathrm{I}$ & $\mathrm{M}, \mathrm{H}, \mathrm{P}$ \\
\hline Mosan & $\mathrm{J}$ & 58.47 & 22.55 & 17.25 & 0.42 & 0.71 & 0.59 & 0.0290 & 0.012 & 0.030 & M, Q \\
\hline Mt. Newman & $\mathrm{K}$ & 61.48 & 0.29 & 6.47 & 2.76 & 0.06 & 0.06 & 0.0113 & 0.014 & 0.037 & $\mathrm{H}$ \\
\hline Dempo & $\mathrm{L}$ & 62.60 & 2.04 & 2.44 & 2.26 & 0.03 & 0.08 & 0.0320 & 0.014 & 0.032 & $\mathrm{H}, \mathrm{G}$ \\
\hline Romeral & $\mathrm{M}$ & 66.25 & 28.42 & 3.91 & 0.81 & 1.23 & 0.79 & 0.0670 & 0.031 & 0.026 & $\mathrm{M}$ \\
\hline Rio Doce & $\mathrm{O}$ & 62.31 & 0.46 & 5.82 & 1.26 & 0.15 & 0.13 & 0.0102 & 0.007 & 0.007 & $\mathrm{H}, \mathrm{Q}$ \\
\hline Hamersley & $\mathrm{P}$ & 62.04 & 0.46 & 4.38 & 2.66 & 0.11 & 0.19 & 0.0173 & 0.017 & 0.016 & $\mathrm{H}$ \\
\hline San Ishidro & Q & 68.06 & 0.17 & 1.05 & 0.29 & 0.02 & 0.01 & 0.0071 & 0.004 & 0.005 & $\mathrm{H}, \mathrm{G}$ \\
\hline Carajas & $\mathrm{R}$ & 67.96 & 0.34 & 0.58 & 0.79 & 0.01 & 0.02 & 0.0071 & 0.008 & $0.0 \mathrm{I} 1$ & $\mathrm{H}$ \\
\hline Taharoa & $\mathrm{S}$ & 56.85 & 18.57 & 2.96 & 3.68 & 1.51 & 3.55 & 0.0181 & 0.015 & 0.012 & $\mathrm{M}$ \\
\hline Mt. Newman & $\mathrm{T}$ & 62.89 & 0.30 & 5.50 & 2.74 & 0.05 & 0.11 & 0.0037 & 0.010 & 0.011 & $\mathrm{H}$ \\
\hline Yampi Sound & $\mathrm{U}$ & 66.43 & 0.17 & 3.29 & 1.21 & 0.07 & 0.03 & 0.0056 & 0.006 & 0.007 & $\mathrm{H}$ \\
\hline
\end{tabular}

*: original ores, **: ore diameter; $149-210 \mu \mathrm{m}$. Alkali dissolved in a $\mathrm{HCl}$ solution is determined using an atomic adsorption spectroscopy. $\mathrm{H}$ : hematite, M: magnetite, G: geothite, Q: quartz, P: pyrite

results using reagents. ${ }^{19-21)}$

The previous researches have also reported some interesting findings ${ }^{7,8)}$ : ores having high alumina content tend to keep a fluidization state with showing plain irons on the surface of ore particles; the addition of gaseous sulfur, able to sulfurize metallic iron, into $\mathrm{H}_{2}$ base gas can realize a fluidized state due to the formation of coarse porous irons.

The iron morphology is probably associated with the adhesive force among ore particles which is one of noticeable parameters enhancing the stickiness stated earlier. Since the morphology is expected to change strongly by several testing variables such as ore type, reducing potential, and sulfur potential on the basis of the above findings, ${ }^{7,8)}$ this work is focused to clarify further the relation between sticking behavior and these testing variables. Therefore, using several brands of ores different from those employed previously, the fluidized bed reduction tests were carried out in this work by $\mathrm{N}_{2}-\mathrm{H}_{2}$ mixtures which possess three reducing potentials without sulfur and with adding two levels of sulfur activities, namely $a_{s}<1$ or $a_{s}>1$.

Moreover, this paper discusses about dominant factors controlling the fluidization behavior using the test results obtained for many kinds of ores (19 ores A-U, see later Table 1).

\section{Experiments}

The chemical compositions and main mineral phases for 19 kinds of iron ores $\mathrm{A}-\mathrm{U}$ are shown in Table 1, where 15 ores $\mathrm{A}-\mathrm{P}$ and $\mathrm{S}$ and 7 ores $\mathrm{O}-\mathrm{U}$ were employed in our previous study ${ }^{8)}$ and this work, respectively. Most of last 7 ores consisting of hematite and containing various levels of gangue and sulfur were selected as those showing either fluidization or sticking based on the preliminary reduction tests.

Using a previous experimental apparatus, ${ }^{8)}$ batches of $20 \mathrm{~g}$ of each ore with a particle size between 149 and
Table 2. Condition of $\mathrm{N}_{2}-\mathrm{H}_{2}$ gas mixtures.

\begin{tabular}{|c|c|c|c|c|c|}
\hline \multirow[b]{2}{*}{$\begin{array}{c}\text { Gas } \\
\text { mixture }\end{array}$} & \multicolumn{3}{|c|}{ Inlet } & \multicolumn{2}{|c|}{ at $900^{\circ} \mathrm{C}$} \\
\hline & $\mathrm{N}_{2}$ & ${ }_{1} \mathrm{H}_{2}$ & $\begin{array}{c}P_{\mathrm{H}_{2}} \\
(\mathrm{~atm})\end{array}$ & $\begin{array}{c}U_{m f} \\
(\mathrm{~cm} / \mathrm{s})\end{array}$ & $U / U_{m f}$ \\
\hline G-A & 0.5 & 3.0 & 0.857 & 4.12 & 14.9 \\
\hline G-B & 1.0 & 2.0 & 0.667 & 3.42 & 15.4 \\
\hline $\mathrm{G}-\mathrm{C}$ & 1.5 & 1.0 & 0.400 & 3.14 & 14.0 \\
\hline
\end{tabular}

$U_{m f}:$ superficial gas velocity at minimum fluidization; Refs. 7), 22), $U$ : superficial velocity of gas mixture $(\mathrm{cm} / \mathrm{s})$

$210 \mu \mathrm{m}$ were reduced at $900^{\circ} \mathrm{C}$ under atmospheric pressure in a bubbling fluidized state. The reactor is made of transparent silica with an inner diameter of $2.2 \mathrm{~cm}$. The compositions and gas flow rates of three types of $\mathrm{N}_{2}-\mathrm{H}_{2}$ mixtures having different levels of reducing potentials, called G-A, B, and C, are listed in Table 2, whose superficial gas velocities $U$ are 14.0-15.4 times greater than those at minimum fluidization $U_{m f},{ }^{7,22)}$ indicating that the gases have the nearly same kinetic energy for stirring a bed. The tests with $\mathrm{H}_{2} \mathrm{~S}$ addition corresponding to inlet $a_{s}=0.256$ and 1.28 to gas mixtures were also carried out based on statement in Chap. 1 and some values $a_{s}$ evaluated in industry (Sec. 5.2). The gas ratio under $\mathrm{Fe} / \mathrm{FeS}$ equilibrium $P_{\mathrm{H}_{2} \mathrm{~S}} / P_{\mathrm{H}_{2}}=3.9 \times 10^{-3}$ was employed for $a_{s}=1$ at $900^{\circ} \mathrm{C}^{23)}$ The reduction progress was measured by the difference between inlet and outlet gas flow rates after the removal of steam produced by the reduction. The sulfur activity in a bed was evaluated assuming $\mathrm{Fe} / \mathrm{FeO}$ equilibrium, ${ }^{24)}$ by means of analyzing chemically total sulfur in the gas exhausted throughout the reduction. The sticking time can be detected by an abrupt fall of pressure drop across the bed monitored by a pressure sensor. Either when sticking and when reaching near the complete reduction, just at their times or when being fluidized halfway the reduction, at the longest $15 \mathrm{~min}$, the reducing gas was changed into $\mathrm{N}_{2}$ gas and the bed was rapidly cooled into the room temperature. The fractional reduction $R(-)$ in 
both cases of fluidization and sticking was determined by reoxidizing the reduced ore in air, based on the completely oxidizing stage of total iron in the ores. The surface morphology was observed using a scanning electron microscopy (SEM).

\section{Experimental Results}

\subsection{Reduction Tests without $\mathrm{H}_{2} \mathrm{~S}$ Addition}

Figures 1 and 2 show fractional reduction $R(-)$, reduction time (min), and aspect of bed (F: fluidization, no mark : sticking) obtained in the tests with G-A, B, and $\mathrm{C}$ at inlet $a_{s}=0$ for 3 ores $\mathrm{O}-\mathrm{Q}$ and 4 ores $\mathrm{R}-\mathrm{U}$, respectively. Ores $\mathrm{P}$ and $\mathrm{S}$ (iron sand) kept fluidized states until nearly complete reduction and a higher reduction level respectively, while other five ores sticked as soon as incipient metallization $(R=0.30)$. Most of the sticked ores inclined to exhibit high $R$ values and short reduction times with increasing the reduction potential.

The sulfur activity in offgas obtained for G-B reduction of 7 ores $\mathrm{O}-\mathrm{U}$ at inlet $a_{s}=0$ ranged in 0.01-0.1.

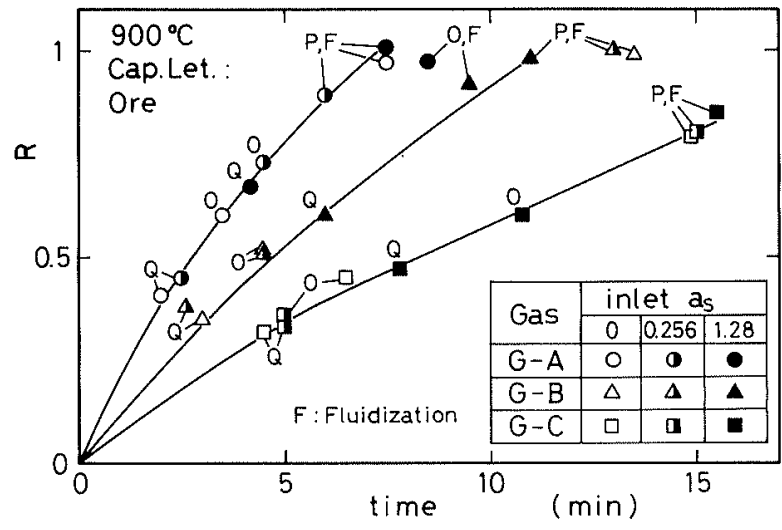

Fig. 1. Relation between fractional reduction and reduction time for 3 ores $O-Q$.

Solid curves: empirical results of 7 ores $\mathrm{O}-\mathrm{U}$ except ore $\mathrm{S}$
These values are plotted against $R$ values in Fig. 3, where the results ${ }^{8)}$ obtained previously for other 12 ores $A-M$ are also included. The activity range for all of 19 ores is

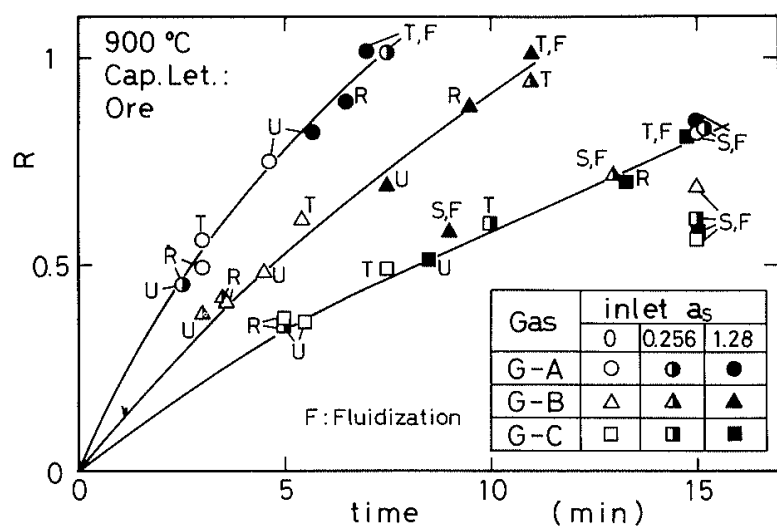

Fig. 2. Relation between fractional reduction and reduction time for 4 ores R-U.

Solid curves: empirical results of 7 ores $\mathrm{O}-\mathrm{U}$ except ore $\mathrm{S}$

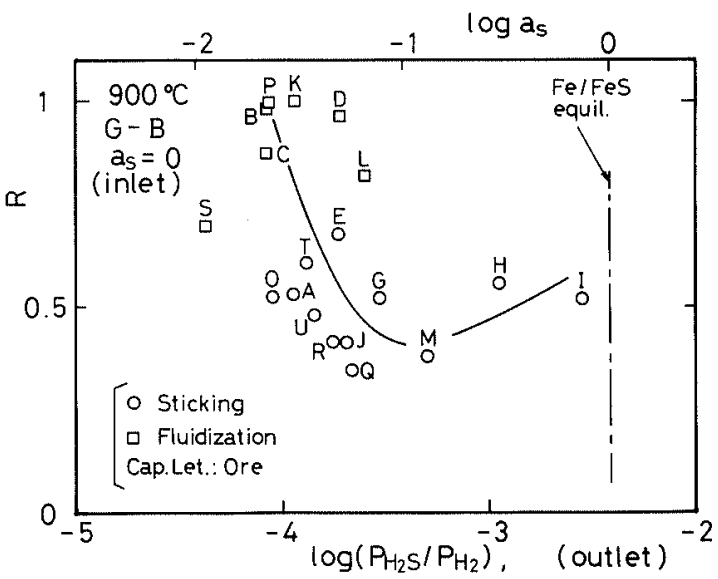

Fig. 3. Relation between outlet $a_{s}$ and fractional reduction for $\mathrm{G}-\mathrm{B}$ reduction of 19 ores.
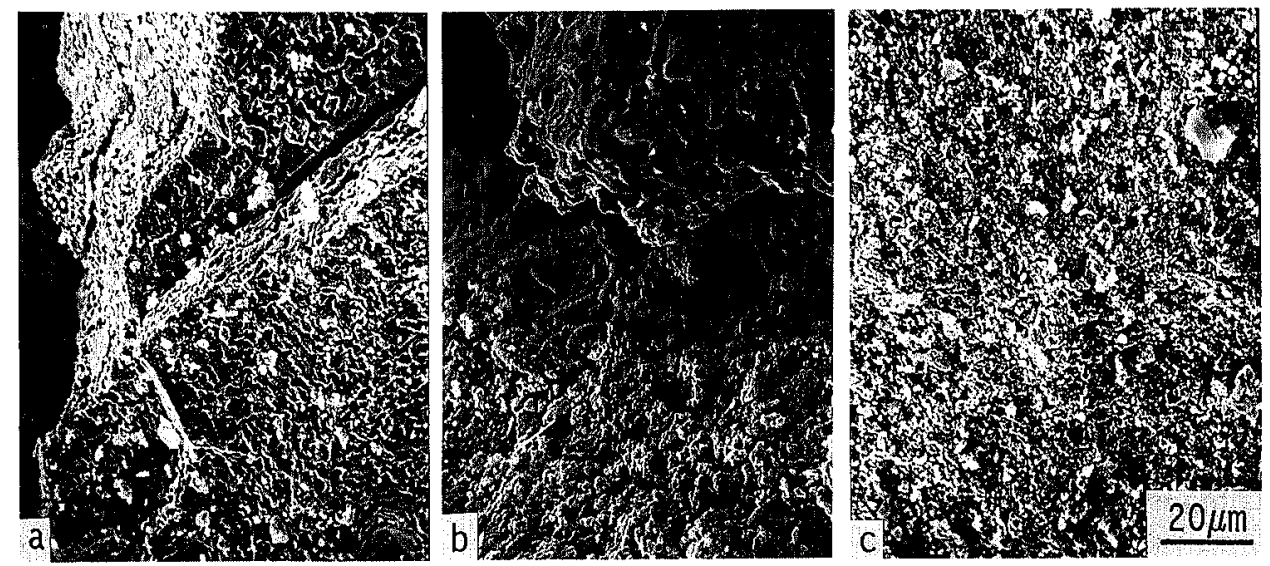

Fig. 4. External views of reduced ores under SEM (G-B at inlet $a_{s}=0$ ).

\begin{tabular}{ccccclc}
\hline No. & Ore & $\mathrm{Al}_{2} \mathrm{O}_{3}$ content & Outlet $a_{s}$ & $R$ & \multicolumn{1}{c}{ Bed } & Iron morphology \\
\hline $\mathrm{a}$ & $\mathrm{O}$ & $\mathrm{L}$ & 0.023 & 0.52 & Sticking & sfi $+\mathrm{pi}$ \\
$\mathrm{b}$ & $\mathrm{I}$ & $\mathrm{L}$ & 0.721 & 0.50 & Sticking & pi \\
$\mathrm{c}$ & $\mathrm{K}$ & $\mathrm{H}$ & 0.030 & 1.01 & Fluidization & pli \\
\hline
\end{tabular}

L: low; < $1.3 \mathrm{wt} \%$, H: high; $>2 \mathrm{wt} \%$, sfi: short fibrous iron, pi: porous iron, pli: plain iron 
in $0.01-1$ and the minimum of an empirical curve drawn in the figure lies near $a_{s}=0.1$. These results coincided with the sulfur activity dependence of swelling with fibrous irons which had been found out in the authors' works. ${ }^{20,21)}$ These values of outlet $a_{s}$ had also roughly a relation to sulfur contents in original ores, being analogous to those obtained by the authors' previous study. ${ }^{8)}$

Eleven kinds of ores having low $\mathrm{Al}_{2} \mathrm{O}_{3}$ content below $1.3 \mathrm{wt} \%$ were in the range of outlet $a_{s}=0.01-1$ and sticked soon after initial metallization accompanied with short iron whiskers and/or porous irons, as shown typically in Figs. $\mathbf{4 a}$ and $\mathbf{4 b}$. On the other hand, 8 kinds of ores having high $\mathrm{Al}_{2} \mathrm{O}_{3}$ content above $2 \mathrm{wt} \%$ showed low sulfur activities of outlet $a_{s}=0.01-0.1$ and most of their beds were fluidized until nearly complete re-

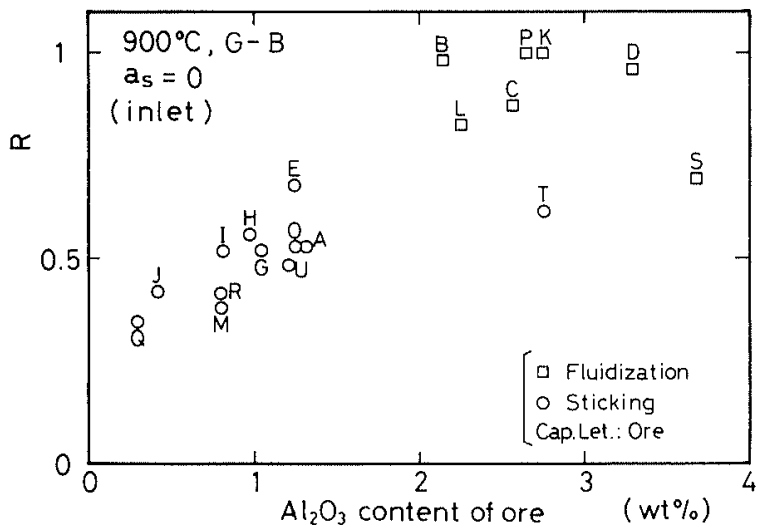

Fig. 5. Relation between $\mathrm{Al}_{2} \mathrm{O}_{3}$ content of ore and fractional reduction for $\mathrm{G}-\mathrm{B}$ reduction of 19 ores without sulfur addition.
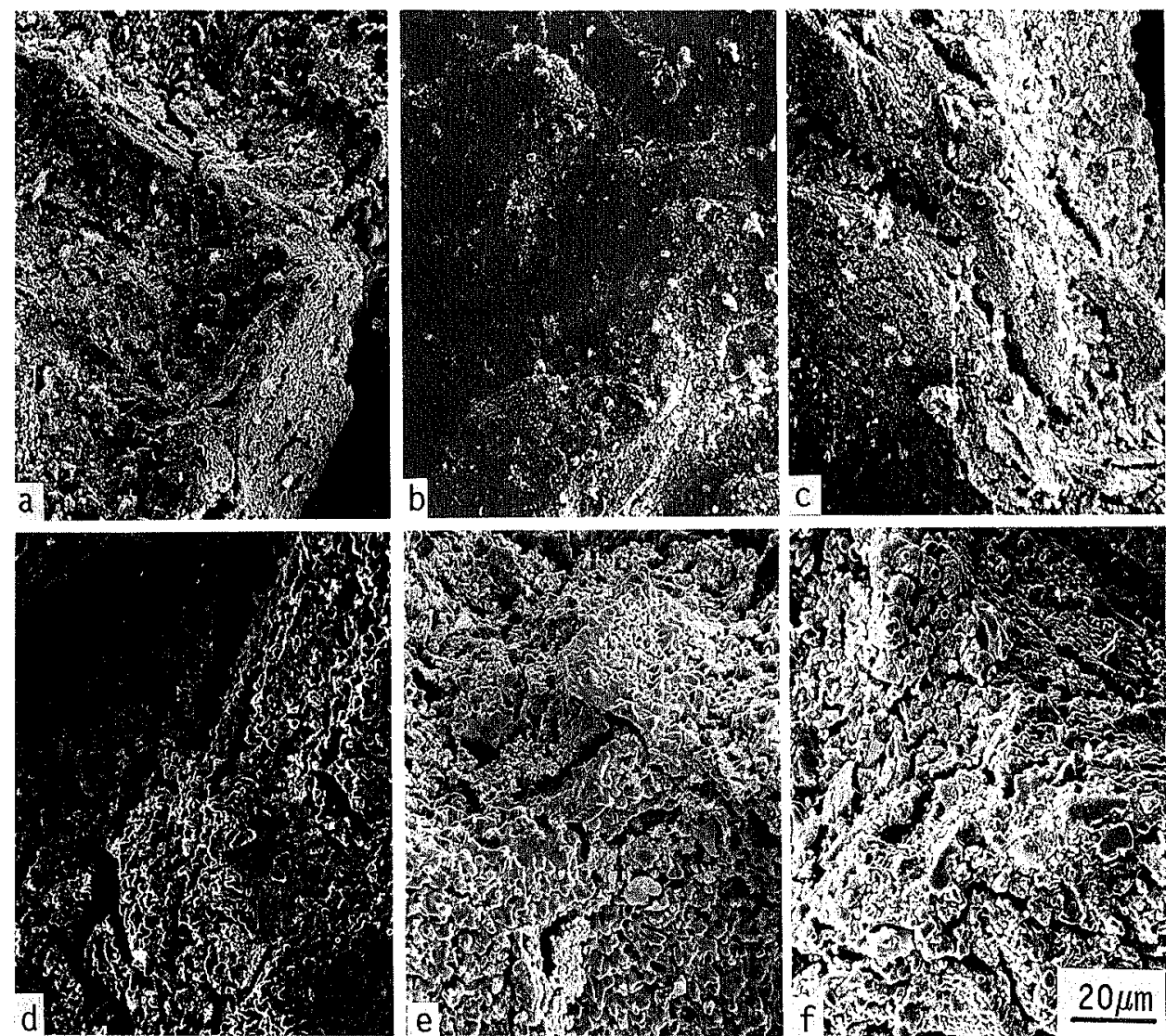

duction due to plain irons without whiskers as shown in Fig. 4c.

The intimate relation between $R$ values and alumina content of ore for G-B reduction of 19 ores was recognized as shown in Fig. 5 despite no relation with $\mathrm{SiO}_{2}$ content of ore. The values $R$ at sticking increased with increasing $\mathrm{Al}_{2} \mathrm{O}_{3}$ content up to $1.3 \mathrm{wt} \%$. Above $2 \mathrm{wt} \% \mathrm{Al}_{2} \mathrm{O}_{3}$ the major beds were under fluidization near the complete reduction except ore $T$.
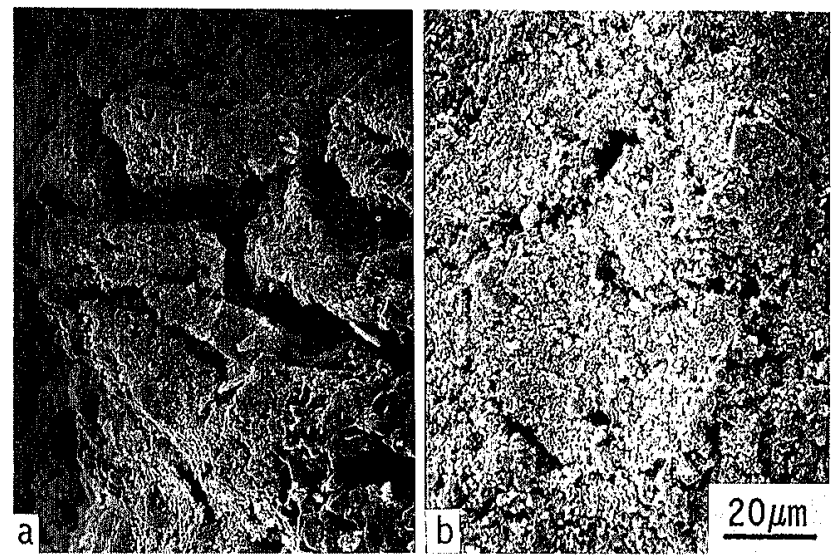

Fig. 6. External views of reduced ores under SEM (G-B).

\begin{tabular}{ccccccc}
\hline No. & Ore & $\begin{array}{c}\mathrm{Al}_{2} \mathrm{O}_{3} \\
\text { content }\end{array}$ & $\begin{array}{c}\text { Inlet } \\
a_{s}\end{array}$ & $R$ & Bed & $\begin{array}{c}\text { Iron } \\
\text { morphology }\end{array}$ \\
\hline $\mathrm{a}$ & $\mathrm{O}$ & $\mathrm{L}$ & 1.28 & 0.92 & Fluidization & $\mathrm{cpi}$ \\
$\mathrm{b}$ & $\mathrm{P}$ & $\mathrm{H}$ & 1.28 & 0.98 & Fluidization & pci \\
\hline
\end{tabular}

L: low; $<1.3 \mathrm{wt} \%, \mathrm{H}$ : high; $>2 \mathrm{wt} \%$, cpi: coarse porous iron, pci: plain coarse iron

Fig. 7.

External views of reduced ore $Q$ under SEM.

Reduction results: see Fig. I

\begin{tabular}{ccccccc}
\hline No. & a & $b$ & $c$ & $d$ & $c$ & f \\
\hline Gas & G-A & G-B & G-C & G-A & G-B & G-C \\
Inlel & 0 & 0 & 0 & 1.28 & 1.28 & 1.28 \\
$a_{s}$ & & & & & &
\end{tabular}




\subsection{Reduction Tests with $\mathbf{H}_{2} \mathbf{S}$ Addition}

Seven ores $\mathrm{O}-\mathrm{U}$ were reduced in $\mathrm{G}-\mathrm{A}, \mathrm{B}$, and $\mathrm{C}$ with $\mathrm{H}_{2} \mathrm{~S}$ addition corresponding to $a_{s}=0.256$ or 1.28 . The obtained results are included in Figs. 1 and 2.

In the tests with $a_{s}=0.256$ in inlet gas, both product morphologies and bed aspect were entirely similar to those observed in the case of inlet $a_{s}=0$. However, ore $\mathrm{T}$ fluidized for $\mathrm{G}-\mathrm{A}$ reduction and showed higher values of $R$ for G-B and C reduction than that in inlet $a_{s}=0$. Inversely, the reduction tests of ore $\mathrm{U}$ by three gases gave lower values of $R$ than the case of inlet $a_{s}=0$. Except such ores $\mathrm{T}$ and $\mathrm{U}$, other values of $R$ were comparable to those without $\mathrm{H}_{2} \mathrm{~S}$ addition.

On the other hand, in the tests with $a_{s}=1.28$ in inlet gas the values of $R$ for ores $\mathrm{O}, \mathrm{Q}, \mathrm{R}, \mathrm{T}$, and $\mathrm{U}$ were intensively higher than those in the case of inlet $a_{s}=0.256$. Ores $\mathrm{O}$ and $\mathrm{T}$ could be fluidized until nearly complete reduction with coarse porous irons as shown in Fig. 6a, except the test of ore $\mathrm{O}$ with $\mathrm{G}-\mathrm{C} . \mathrm{H}_{2} \mathrm{~S}$ addition of $a_{s}=1.28$ to ores $\mathrm{P}$ and $\mathrm{S}$ showing no sticking at the tests of inlet $a_{s}=0 \mathrm{kept}$ fluidized and gave plain coarse irons as seen in Fig. 6b.

As clearly shown in Figs. 1 and 2, depending on reducing potential, but not on inlet $a_{s}$ and ore kinds, the relation between reduction time and fractional reduction obtained for the tests of 7 ores $\mathrm{O}-\mathrm{U}$ could be divided into three groups being represented by their empirical solid curves, exclusive of ore $\mathrm{S}$ (iron sand). With increasing the reducing potential, their overall reduction proceeded more rapidly. Their reduction rates will be analyzed in Chap. 4.

Typical morphologies obtained by reduction of ore $\mathrm{Q}$ with G-A, B, and C at inlet $a_{s}=0$ and 1.28 are shown in Figs. 7a to 7f. Without and with sulfur addition, porous irons and coarse porous irons predominate, respectively. They will be discussed in Sec. 5.1.

Figure 8 shows the relation between $\mathrm{Al}_{2} \mathrm{O}_{3}$ content of ore and $R$ values for G-B reduction at inlet $a_{s}=1.28$. Compared with the case of inlet $a_{s}=0$ in Fig. 5, most of tests below $1.3 \% \mathrm{Al}_{2} \mathrm{O}_{3}$ gave higher values of $R$ and ores, $\mathrm{E}, \mathrm{G}, \mathrm{H}$, and $\mathrm{O}$ kept fluidized states until nearly complete reduction. Ore $\mathrm{T}$ having high $\mathrm{Al}_{2} \mathrm{O}_{3}$ content was also fluidized.

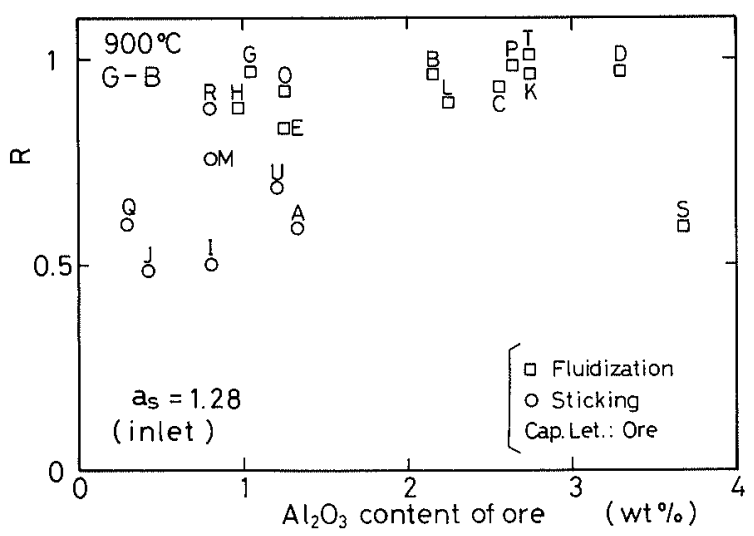

Fig. 8. Relation between $\mathrm{Al}_{2} \mathrm{O}_{3}$ content of ore and fractional reduction for G-B reduction of 19 ores with inlet $a_{s}=1.28$.

\section{Rate Analysis}

This work is concerned with iron morphology so that the overall rate of ores in a bed during metallization process should be important to be analyzed. The metallization begins at the stage where the ore bed is reduced until wustite under $\mathrm{Fe} / \mathrm{FeO}$ equilibrium $(R=0.30)$. X-ray diffraction confirmed that when an initial nucleation of iron occurred, only wustite phase existed as iron oxides. Assuming gas supply control, the rate $v(\mathrm{~mol} / \mathrm{s})$, can be estimated by Eq. (1).

$$
v=A U\left(C_{\mathrm{H}_{2}}^{b}-C_{\mathrm{H}_{2}}^{e}\right)
$$

where $A$ is a cross section area in a reaction tube $\left(\mathrm{cm}^{2}\right)$, $U$ is a superficial gas velocity at reaction temperature $(\mathrm{cm} / \mathrm{s})$, and $C_{\mathrm{H}_{2}}^{b}$ and $C_{\mathrm{H}_{2}}^{e}$ and hydrogen contents in bulk gas phase and at $\mathrm{Fe} / \mathrm{FeO}$ equilibrium $\left(\mathrm{mol} / \mathrm{cm}^{3}\right)$, respectively.

The calculated values $10^{4} v$ were $7.9,5.3$, and 2.6 (mol/s) for G-A, B, and C, respectively. Their corresponding broken lines are drawn in the range of $R \geq 0.30$ in Fig. 9 together with measured solid curves shown in Figs. 1 and 2 as the rates $d R / d t\left(\min ^{-1}\right)$, which were converted using an average oxygen content of 7 ores, $27.41 \mathrm{wt} \%$. Comparing calculated rates with measured, the formers tend to become just a little larger

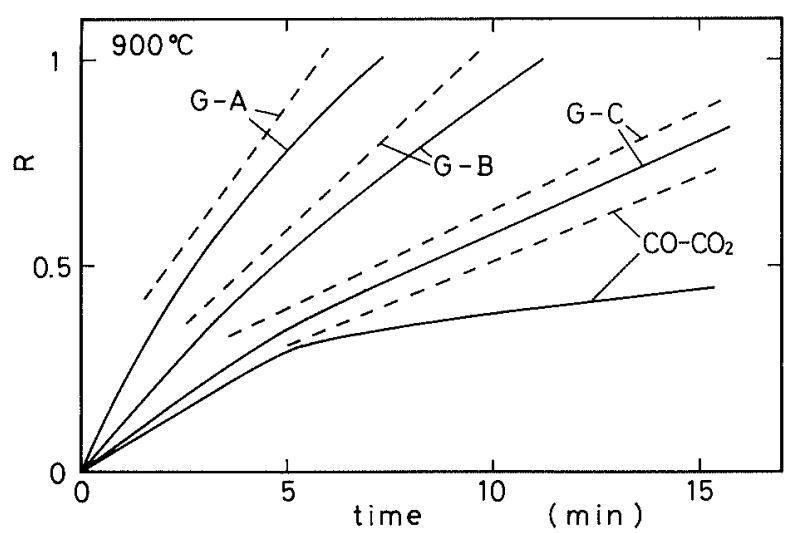

Fig. 9. Comparison of measured results with calculated for reduction progress in $\mathrm{G}-\mathrm{A}, \mathrm{B}$, and $\mathrm{C}$, including previous $90 \% \mathrm{CO}-10 \% \mathrm{CO}_{2}$ fluidized bed reduction of 11 ores $A-M^{7)}$

Solid curves: measured, using three curves in Figs. 1 and 2, broken lines: calculated assuming gas supply control by Eq. (1)

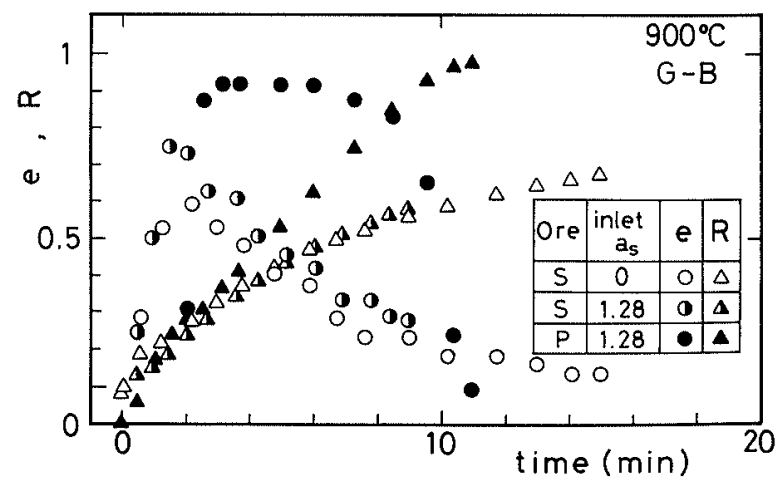

Fig. 10. Gas utilization and fractional reduction obtained from outlet gas analysis. 
than the latters with increasing reducing potential. However, both the rates appear to be almost equivalent each other for individual three gases. Therefore, it was confident that the overall reaction of metallization in a bed should proceed under gas supply control except ore $\mathrm{S}$. This is probably attributed to the high chemical reaction rate of ores with hydrogen, the fast gas diffusion rate through pores in the ores, and the sufficiently great mass transfer rate between both phases of gas bubble and emulsion within the ore bed.

The above result is also supported by a finding that the gas utilization based on $\mathrm{Fe} / \mathrm{FeO}$ equilibrium during metallization $e(-)$ exceeds 0.9 for $\mathrm{G}-\mathrm{B}$ reduction of a typical ore $\mathrm{P}$ as shown in Fig. 10. Both of the utilizations $e$ and the values $R$ in the figure can be calculated using outlet gas compositions measured as a function of reduction time.

As shown in Fig. 9, for the previous $90 \% \mathrm{CO}-10 \% \mathrm{CO}_{2}$ fluidized bed reduction of 11 ores (gas flow rate: 1.5 $\mathrm{Nl} / \mathrm{min}),{ }^{7)}$ the empirical overall rate obtained during metallization process was roughly one third less than that calculated similarly by Eq. (1). This supposes an existence of substantial resistances for chemical reaction and/or gas diffusion through pores within ore fines. The similar finding was observed in the case of ore $S$ which is not easy to be reduced, whose less gas utilization being illustrated in Fig. 10.

\section{Discussion}

\subsection{Reducing Potential}

Although the iron morphology did not change much despite shifting reducing potential as shown typically in Fig. 7 (ore Q), the time required from initial metallization $(R=0.30)$ until sticking and the fractional metallization at sticking for reduction of ores $\mathrm{Q}, \mathrm{R}$, and $\mathrm{U}$ in $\mathrm{G}-\mathrm{A}-\mathrm{C}$ were evidently variant as listed in Table 3 . It is considered that the longer the times, the less the stickiness. The results of this table could be explained as follows. In case of inlet $a_{s}=0$, with lowering the potential, the times become shorter, likely due to having a tendency for the iron whiskers to be easily formed, so that the fractional metallization becomes less. In case of inlet $a_{s}=1.28$, inversely with a decrease in the potential the times become longer except ore $U$. This is possibly caused by having an inclination for the porous irons to become coarser, so that the fractional metallization becomes less because

Table 3. Time required from initial metallization until sticking (min) and fractional metallization at sticking.

\begin{tabular}{lllllll}
\hline \multirow{2}{*}{ Ore } & \multicolumn{5}{c}{0} & \multicolumn{3}{c}{ Inlet $a_{s}$} & 1.28 \\
& G-A & G-B & G-C & G-A & G-B & G-C \\
\hline \multirow{2}{*}{$\mathrm{Q}$} & 0.5 & 0.4 & 0.2 & 2.7 & 3.4 & 3.5 \\
& 0.16 & 0.071 & 0.029 & 0.53 & 0.43 & 0.24 \\
$\mathrm{R}$ & 1.5 & 1.0 & 0.7 & 5.0 & 6.9 & 9.0 \\
& 0.27 & 0.16 & 0.10 & 0.84 & 0.83 & 0.57 \\
$\mathrm{U}$ & 3.1 & 1.9 & 1.2 & 4.0 & 4.9 & 4.2 \\
& 0.64 & 0.26 & 0.086 & 0.74 & 0.56 & 0.30 \\
\hline
\end{tabular}

lowers: fractional metallization at sticking the difference among the times is slight. In such discussion, the oxygen potential dependence of surface energy of iron, which is described in Sec. 5.3, need not be taken into account, because the potential in a bed during metallization is expected to be almost under $\mathrm{Fe} / \mathrm{FeO}$ equilibrium for all of the used gases as having been discussed in Chap. 4.

It may be concluded from the authors' studies of reduction swelling ${ }^{19-21)}$ that in the case of present $\mathrm{N}_{2}-\mathrm{H}_{2}$ reduction short fibrous irons and/or porous irons appeared due to the greater overall reduction rate, while in the case of previous $\mathrm{CO}-\mathrm{CO}_{2}$ reduction ${ }^{7)}$ long fibrous irons were observed due to the relatively lower rate. This is supported by a general knowledge that the growth of iron whiskers predominates under the interfacial chemical reaction control of wustite by reducing gases ${ }^{25}$ ) where the overall reduction rate lies in an intermediate level.

\subsection{Sulfur Potential}

As described in Chap. 1, we had accomplished gaseous redution of iron oxide pellets prepared from reagents under various sulfur potentials and observed abnormal swelling characterized by the formation of numerous iron whiskers in the condition of $a_{s}=0.01-1$ together with the maximum around $a_{s}=0.1$ where long fine whiskers appeared preferentially. ${ }^{19-21)}$ Similar results concerning sulfur potential and iron morphology were also recognized in the authors' fluidized bed reduction of iron ores with either $\mathrm{CO}-\mathrm{CO}_{2}{ }^{7)}$ or $\mathrm{N}_{2}-\mathrm{H}_{2}{ }^{8)}$ The results of Fig. 3 obtained for reduction of 19 types of ores by the latter gas mixture indicated the sulfur potential range similar to those as described above. However, not long whiskers, but short fibrous irons and/or porous irons were found as shown in Chap. 3.

The mechanism to interpret morphology change of metallic iron produced in the condition of $a_{s}<1$ is described in our previous researches ${ }^{19-21,26)}$ in detail, which is based on the sulfur adsorption on both the surfaces of wustite and iron and into the interface between them. In this case, the iron atoms precipitate directly from wustite lattices through an electrochemical reaction into the $\mathrm{Fe} / \mathrm{FeO}$ interface. ${ }^{26)}$ On the other hand, in the case of $a_{s}>1$ they have to precipitate across a thin layer of small amounts of iron oxysulfide liquid formed in $\mathrm{Fe} / \mathrm{FeO}$ interface, so that coarse iron particles might be observed probably due to the so-called liquid phase sintering. ${ }^{27)}$

A substantial amount of gaseous sulfur originated from reductants always exists in various conventional industrial processes of ironmaking. Accordingly, it may be important to consider the influence of sulfur on some cases. In case of gasification of coal using an iron bath, ${ }^{28)}$ the sulfur activity in the gas becomes fairly poor to be roughly $a_{s}=0.05$ due to desulfurization by basic slag. The use of this gas to a fluidized prereduction furnace likely enhances sticking because of the preferential formation of fibrous irons. When the high temperature gas exhausted after post combustion in a smelting reduction furnace is converted adiabatically into a highly reducing gas by the addition of fine coal with $1 \mathrm{wt} \% \mathrm{~S}$, 
the value $a_{s}$ in the gas is expected to become rich around $\mathrm{Fe} / \mathrm{FeS}$ equilibrium if all of sulfur in coal is transferred to the gas phase. This case supposes a fair possibility of stable fluidization regardless of ore kinds, owing to appearance of coarse irons on the surface of ore particles. $^{8)}$

\subsection{Several Factors Affecting Fluidization \\ (1) Gangue}

Considering the results obtained for tests of 19 ores with G-B, the bed aspect signifying either fluidization or sticking had no certain relation with main phases of the used ores as well as with $\mathrm{SiO}_{2}$ content of ore. However, it associated surely with $\mathrm{Al}_{2} \mathrm{O}_{3}$ content of ore as shown in Figs. 5 and 8.

Neuschütz and Foster ${ }^{5)}$ reduced 10 types of ores in a fluidized state with a $90 \% \mathrm{CO}-10 \% \mathrm{H}_{2}$ mixture at $800^{\circ} \mathrm{C}$ and indicated for hematite ores containing goethite that while three kinds of the ores easily fluidized, a couple of the ores sticked, showing no correlation between the bed aspect and goethite. These results coincide with ours. Their surface observation of the reduced ores under SEM was also analogous to those seen in Figs. 4 and 6.

Miyagawa et al. $^{6}{ }^{6}$ reduced 8 types of ores in a fluidized state with a $80 \% \mathrm{CO}-20 \% \mathrm{H}_{2}$ mixture at $850^{\circ} \mathrm{C}$ and found that five kinds of hematite ores having a low level of gangues such as $\mathrm{Al}_{2} \mathrm{O}_{3}$ sticked during initial metallization. Their results support the above present work.

(2) $\mathrm{Al}_{2} \mathrm{O}_{3}$ within Ore

To investigate a role of $\mathrm{Al}_{2} \mathrm{O}_{3}$ for reduction behavior, lattice parameters of 19 ores were determined using a $\mathrm{X}$-ray diffractometer, which are shown in Fig. 11 against $\mathrm{Al}_{2} \mathrm{O}_{3}$ content of ore. Ores $\mathrm{D}$ and $\mathrm{L}$ consisting of hematite are expected to dissolve $\mathrm{Al}_{2} \mathrm{O}_{3}$ to a large extent into their

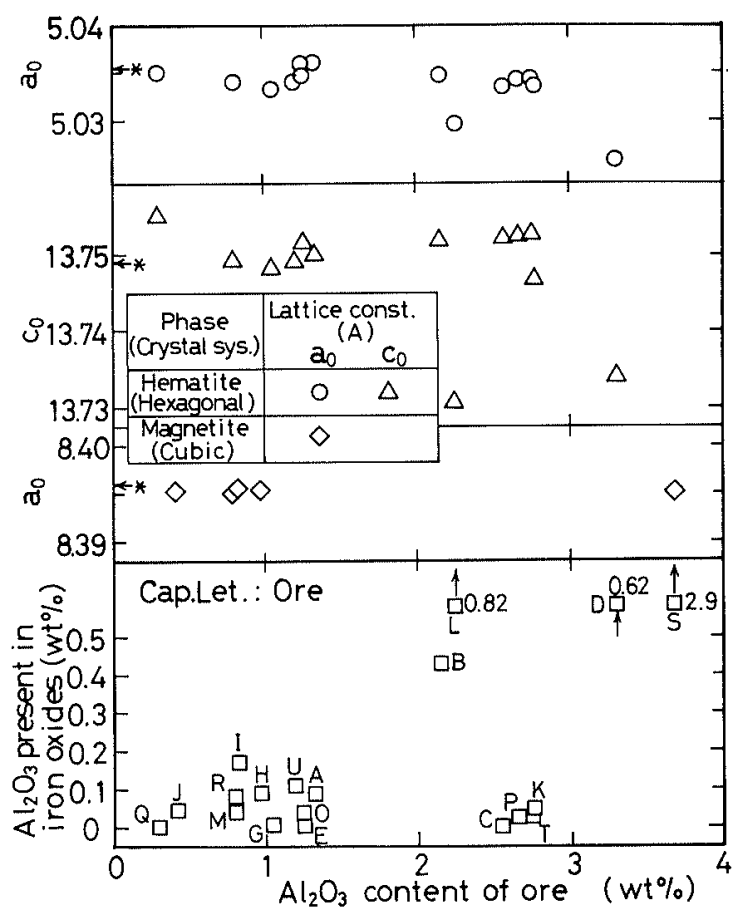

Fig. 11. Lattice constant and $\mathrm{Al}_{2} \mathrm{O}_{3}$ content present in iron oxides for 19 ores. *: ASTM cards
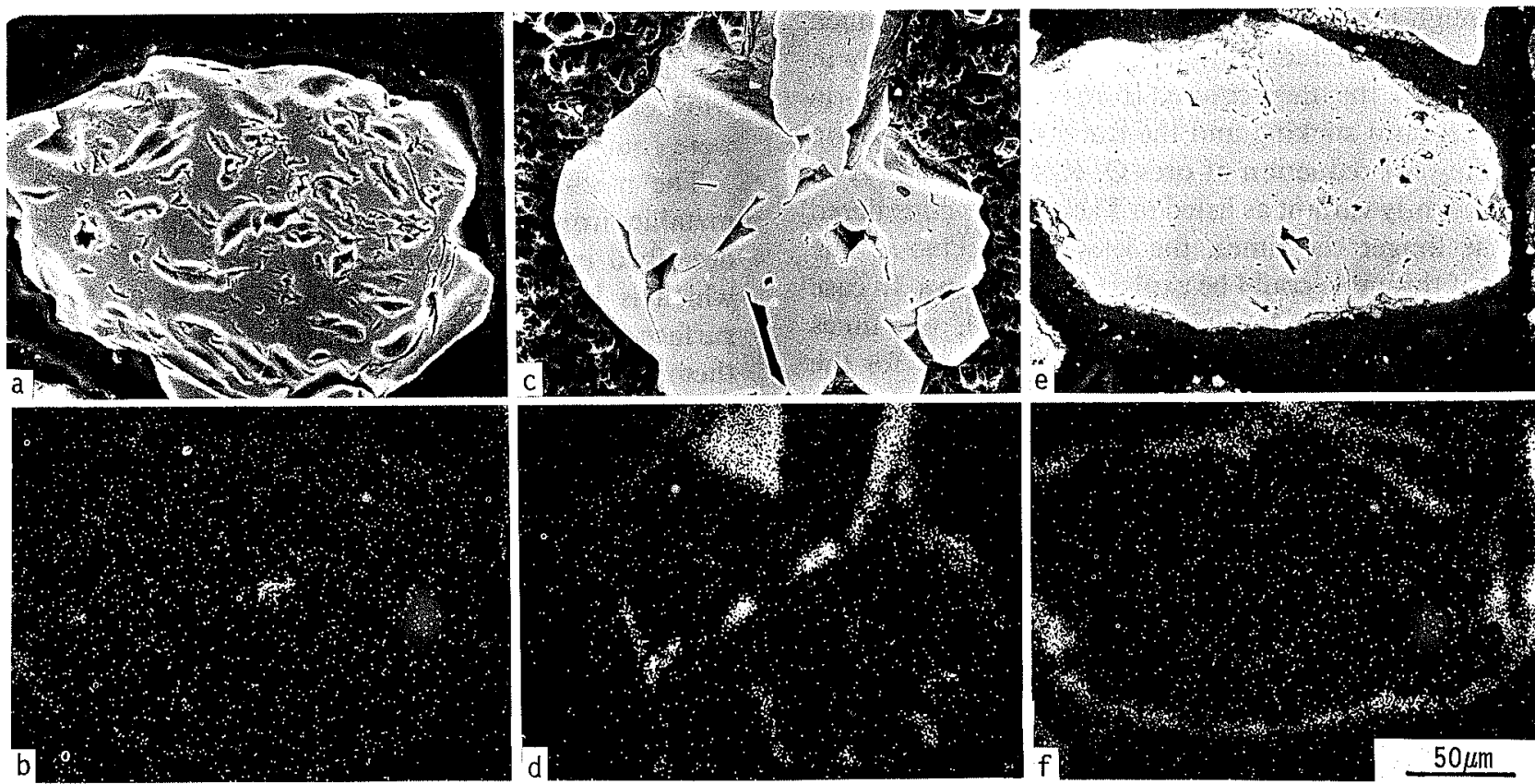

Fig. 12. Al K $\alpha$ radiation map in cross section of ore fines before reduction and fluidization aspect.

\begin{tabular}{cccccc}
\hline $\begin{array}{c}\text { Photo } \\
\text { No. }\end{array}$ & Ore & $\begin{array}{c}\text { External } \\
\text { ore shape* }\end{array}$ & $\begin{array}{c}\text { Total } \mathrm{Al}_{2} \mathrm{O}_{3} \\
(\mathrm{wt} \%)\end{array}$ & $\begin{array}{c}\mathrm{Al}_{2} \mathrm{O}_{3} \text { content** } \\
(\mathrm{wt} \%)\end{array}$ & $\begin{array}{c}\text { Reduction } \\
\left(\mathrm{G}-\mathrm{B} \text { at inlet } a_{s}=0\right)\end{array}$ \\
\hline $\mathrm{a}, \mathrm{b}$ & $\mathrm{M}$ & $\mathrm{R}$ & 0.81 & 0.04 & $R=0.35$, sticking \\
c, d & $\mathrm{O}$ & $\mathrm{R}$ & 1.26 & 0.04 & $R=0.52$, sticking \\
$\mathrm{e}, \mathrm{f}$ & $\mathrm{P}$ & $\mathrm{S}$ & 2.66 & 0.02 & $R=0.99$, fluidization \\
\hline
\end{tabular}

*: see Fig. 13, **: $\mathrm{Al}_{2} \mathrm{O}_{3}$ content present in iron oxide by EPMA (Fig. 11), a, c, e: SEM image, b, d, f: Al Ka radiation map 
lattices, while other ores do not almost dissolve it, referred to lattice parameters of iron oxides doped with $\mathrm{Al}_{2} \mathrm{O}_{3}$ measured by Iguchi and Inoue. ${ }^{29}$ Moreover, the contents of $\mathrm{Al}_{2} \mathrm{O}_{3}$ present in bulk iron oxides before reduction were determined by an electron probe microanalyzer (EPMA) using the wavelength dispersive spectroscopy, being added in Fig. 11. Using the intensities of the $\mathrm{Al}$ $\mathrm{K} \alpha$-ray radiated from 15 areas with a diameter of a few $\mu \mathrm{m}$ on the polished sample surface, the contents were evaluated based on the conventional correction. It was found that 15 types of ores had a trace of $\mathrm{Al}_{2} \mathrm{O}_{3}$ below nearly $0.1 \mathrm{wt} \%$, supporting the results of lattice parameters. Figure 12 shows $\mathrm{Al} \mathrm{K} \alpha$ radiation maps in cross sections of typical original ore fines $\mathrm{O}, \mathrm{P}$, and $\mathrm{M}$. With increasing $\mathrm{Al}_{2} \mathrm{O}_{3}$ content of ore, $\mathrm{Al}_{2} \mathrm{O}_{3}$ existing near ore surface appears to become richer. The results obtained in Figs. 11 and 12 suggest that the fluidization aspect is certainly related to their surface contents rather than those present in iron oxides. High $\mathrm{Al}_{2} \mathrm{O}_{3}$ content at the ore surface is likely derived from fine gangues present near the surface. Substantial amounts of this $\mathrm{Al}_{2} \mathrm{O}_{3}$ likely remain on the reduced iron surface so that their existence might facilitate the formation of plain iron or the lowering of surface energy of iron as stated below, leading to a fluidization state.

\section{(3) Surface Energy of Iron}

Okura ${ }^{3)}$ and Gransden et al. ${ }^{11)}$ had found earlier that defluidization is associated with fibrous or nodular irons on ore surface. However, Ores $\mathrm{E}$ and $\mathrm{T}$ sticked regardless of no formation of such irons. This fact makes it necessary to take into account the amount of the surface energy of reduced iron to understand the bed aspect. It is expected that the higher the surface energy of iron, the stronger the adhesive force among ore particles. They will be dependent upon $\mathrm{Al}_{2} \mathrm{O}_{3}$ content on ore surface and $a_{s}$ rather than the oxygen potential, because both the surface energies of $\mathrm{Al}_{2} \mathrm{O}_{3}$ and iron saturated by adatoms of sulfur are reported to be $905 \mathrm{erg} / \mathrm{cm}^{2}$ at $1850^{\circ} \mathrm{C}^{30)}$ and $1500 \mathrm{erg} / \mathrm{cm}^{2}$ around $900^{\circ} \mathrm{C},{ }^{31)}$ respectively, being in fairly low levels compared with that of iron saturated by adatoms of oxygen to be $1700 \mathrm{erg} / \mathrm{cm}^{2}$ at $1410^{\circ} \mathrm{C}^{32)}$ Therefore, the coverage of both species on iron surface is expected to lower fairly the adhesion force among the reduced ore particles, leading to fluidization. It is generally known that sulfur is fairly a stronger surface active agent than oxygen for pure iron.

The coverage of either $\mathrm{Al}_{2} \mathrm{O}_{3}$ or sulfur on the reduced ore surface also strongly change product morphology as shown in Figs. 4 and 6, while the reducing potential surely affects the morphology as stated in Sec. 5.1. Fibrous morphologies will tend to make intensely the bed defluidize rather than coarse ones probably due to their greater friction forces among ore particles.

\section{(4) External Shape of Ore}

Focusing the test results of 11 ores containing $\mathrm{Al}_{2} \mathrm{O}_{3}$ below 1.3 wt $\%$ with inlet $a_{s}=1.28$ as shown in Fig. 8,4 ores fluidized, while other 7 ores could not reach until terminal reduction besides promoting the fractional reduction. This fact supposes a fair influence of external shape of ores on the bed aspect. The shape of 19 ores could be classified into spheroid (S), Rectangular prism (R), and angular (A) types as shown in Fig. 13, where the relation between their types and the fluidization aspect is also included. As expected, the above seven ores belonged to either $\mathrm{R}$ or A type. Therefore, such complicated shapes likely caused the enhancement of friction force among ore fines to make the bed motion inactive. The value $U_{m f}$ for $\mathrm{R}$ or A type particle can be calculated to be approximately twice larger than that for $S$ type particle if considering the sphericity of a particle and the void fraction in a bed at minimum fluidization, ${ }^{22}$ supporting that the latter type of ore can be easily fluidized.

\begin{tabular}{|c|c|c|c|}
\hline Typical SEM image* & $\begin{array}{l}\text { Shape of ore } \\
\text { fines }\end{array}$ & Ore & $\begin{array}{l}\text { G-B reduction } \\
\text { (inlet } a_{s}=1.28 \text { ) }\end{array}$ \\
\hline & $\begin{array}{l}\text { Spheroid } \\
\text { ( S Type) }\end{array}$ & $\begin{array}{l}\underline{B}, \underline{C}, \underline{D}, E, G, \underline{K}, \\
\underline{\underline{L}}, \underline{\underline{P}}, \underline{S}^{* *}, \underline{T},\end{array}$ & $\begin{array}{l}\text { All } \\
\text { Eluidization }\end{array}$ \\
\hline & $\begin{array}{l}\text { Rectangular } \\
\text { prism } \\
(\mathrm{R} \text { Type ) }\end{array}$ & $\begin{array}{l}H^{* *}, I^{* *}, J^{* *}, \\
H^{* *}, 0, R,\end{array}$ & $\begin{array}{l}\text { Fluidization } \\
\text { : Ore } \mathrm{H}, \mathrm{O} \\
\text { Sticking } \\
\text { : Ore I, J, M, R }\end{array}$ \\
\hline & & $A, Q, U$ & $\begin{array}{l}\text { All } \\
\text { Sticking }\end{array}$ \\
\hline & (A Type) & & \\
\hline
\end{tabular}

Fig. 13.

External shapes of 19 types of ores and fluidization aspect.

*: G-B at inlet $a_{s}=0$, **: main phase; magnetite, underlines: high $\mathrm{Al}_{2} \mathrm{O}_{3}$ content of ore; $>2 w t \%$ 


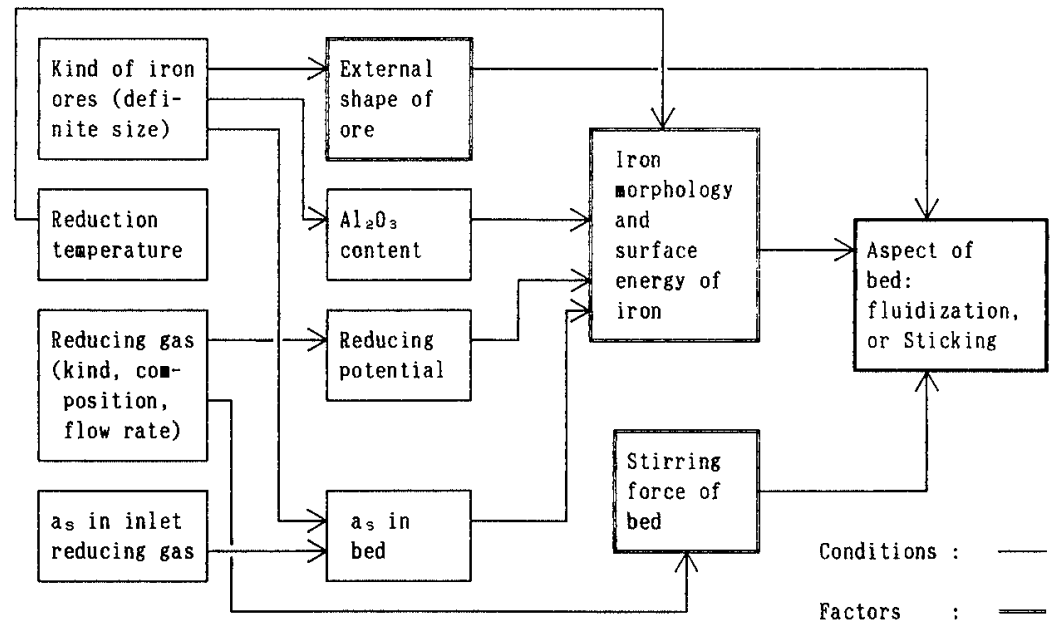

Fig. 14.

Several conditions and factors affecting the aspect of bed.

Table 4. Conditions, factors, and main causes affecting fiuidization behavior for 19 ores under the conditions without or with sulfur addition of inlet $a_{s}=1.28$ (G-B reduction).

\begin{tabular}{|c|c|c|c|c|c|c|c|c|}
\hline Ore & $a$ & $\begin{array}{l}\text { ion } \\
a_{s} \\
\text { in bed }\end{array}$ & $d$ & $\begin{array}{l}\text { Factor } \\
\text { oim }\end{array}$ & $E_{\mathrm{si}}$ & Bed & $R$ & $\begin{array}{c}\text { Ores showing similar behavior } \\
\text { concerning condition, factor, } \\
\text { and bed aspect }\end{array}$ \\
\hline A & $\begin{array}{l}\mathbf{L} \\
\mathbf{L}\end{array}$ & $\begin{array}{l}b \\
c\end{array}$ & $\begin{array}{l}A^{*} \\
A^{*}\end{array}$ & $\underset{\mathrm{cpi}}{(\mathrm{sfi}+\mathrm{pi})^{*}}$ & $\begin{array}{l}\mathrm{h}^{*} \\
1\end{array}$ & $\begin{array}{l}S \\
S\end{array}$ & $\begin{array}{l}0.53 \\
0.59\end{array}$ & $\mathbf{Q}$ \\
\hline B & $\begin{array}{l}\mathrm{H} \\
\mathrm{H}\end{array}$ & $\begin{array}{l}b \\
c\end{array}$ & $\begin{array}{l}\mathrm{S}^{*} \\
\mathrm{~S}^{*}\end{array}$ & $\begin{array}{l}\text { pli* } \\
\text { pci* }\end{array}$ & $\begin{array}{l}1^{*} \\
1^{*}\end{array}$ & $\begin{array}{l}F \\
F\end{array}$ & $\begin{array}{l}0.98 \\
0.96\end{array}$ & $\mathrm{C}, \mathrm{D}, \mathrm{K}, \mathrm{L}, \mathrm{P}, \mathrm{S}$ \\
\hline$E$ & $\begin{array}{l}\mathbf{L} \\
\mathbf{L}\end{array}$ & $\begin{array}{l}b \\
c\end{array}$ & $\begin{array}{l}S \\
S^{*}\end{array}$ & pli & $\begin{array}{l}\mathrm{h}^{*} \\
\mathrm{l}^{*}\end{array}$ & $\begin{array}{l}\mathrm{S} \\
\mathrm{F}\end{array}$ & $\begin{array}{l}0.65 \\
0.87\end{array}$ & \\
\hline $\mathrm{G}$ & $\begin{array}{l}\mathbf{L} \\
\mathbf{L}\end{array}$ & $\begin{array}{l}b \\
c\end{array}$ & $\begin{array}{l}S \\
S^{*}\end{array}$ & $\begin{array}{l}(\mathrm{sfi}+\mathrm{pi})^{*} \\
\mathrm{cpi}^{*}\end{array}$ & $\begin{array}{l}\mathrm{h}^{*} \\
\mathrm{l}^{*}\end{array}$ & $\begin{array}{l}\mathrm{S} \\
\mathrm{F}\end{array}$ & $\begin{array}{l}0.51 \\
0.97\end{array}$ & \\
\hline $\mathrm{H}$ & $\begin{array}{l}\mathbf{L} \\
\mathbf{L}\end{array}$ & $\begin{array}{l}b \\
c\end{array}$ & $\begin{array}{l}\mathrm{R}^{*} \\
\mathrm{R}\end{array}$ & $\begin{array}{l}(\mathrm{sfi}+\mathrm{pi})^{*} \\
\mathrm{cpi}^{*}\end{array}$ & $\begin{array}{l}1 \\
1^{*}\end{array}$ & $\begin{array}{l}\mathrm{S} \\
\mathrm{F}\end{array}$ & $\begin{array}{l}0.53 \\
0.88\end{array}$ & \\
\hline I & $\begin{array}{l}\mathbf{L} \\
\mathbf{L}\end{array}$ & $\begin{array}{l}b \\
c\end{array}$ & $\begin{array}{l}\mathrm{R}^{*} \\
\mathrm{R}^{*}\end{array}$ & $\begin{array}{l}\mathrm{pi} \\
\mathrm{cpi}\end{array}$ & $\begin{array}{l}1 \\
1\end{array}$ & $\begin{array}{l}\mathrm{S} \\
\mathrm{S}\end{array}$ & $\begin{array}{l}0.50 \\
0.50\end{array}$ & \\
\hline $\mathrm{J}$ & $\begin{array}{l}\mathbf{L} \\
\mathbf{L}\end{array}$ & $\begin{array}{l}b \\
c\end{array}$ & $\begin{array}{l}\mathrm{R}^{*} \\
\mathrm{R}^{*}\end{array}$ & $\begin{array}{l}(\mathrm{sfi}+\mathrm{pi})^{*} \\
\mathrm{cpi}\end{array}$ & $\begin{array}{l}h^{*} \\
1\end{array}$ & $\begin{array}{l}S \\
S\end{array}$ & $\begin{array}{l}0.38 \\
0.49\end{array}$ & $\mathrm{M}$ \\
\hline $\mathrm{O}$ & $\begin{array}{l}\mathrm{L} \\
\mathrm{L}\end{array}$ & $\begin{array}{l}b \\
c\end{array}$ & $\begin{array}{l}\mathrm{R}^{*} \\
\mathrm{R}\end{array}$ & $\begin{array}{l}(\mathrm{sfi}+\mathrm{pi})^{*} \\
\mathrm{cpi}^{*}\end{array}$ & $\begin{array}{l}h^{*} \\
1^{*}\end{array}$ & $\begin{array}{l}\mathrm{S} \\
\mathrm{F}\end{array}$ & $\begin{array}{l}0.52 \\
0.92\end{array}$ & \\
\hline $\mathrm{R}$ & $\begin{array}{l}\mathrm{L} \\
\mathrm{L}\end{array}$ & $\begin{array}{l}b \\
c\end{array}$ & $\begin{array}{l}\mathrm{R}^{*} \\
\mathrm{R}^{*}\end{array}$ & $\begin{array}{l}\text { pi } \\
\text { cpi }\end{array}$ & $\begin{array}{l}\mathrm{h}^{*} \\
\mathrm{l}\end{array}$ & $\begin{array}{l}\mathrm{S} \\
\mathrm{S}\end{array}$ & $\begin{array}{l}0.41 \\
0.88\end{array}$ & \\
\hline $\mathrm{T}$ & $\begin{array}{l}\mathrm{H} \\
\mathrm{H}\end{array}$ & $\begin{array}{l}b \\
c\end{array}$ & $\begin{array}{l}S \\
S^{*}\end{array}$ & $\begin{array}{l}\text { pli } \\
\text { pci* }\end{array}$ & $\begin{array}{l}h^{*} \\
1^{*}\end{array}$ & $\begin{array}{l}S \\
F\end{array}$ & $\begin{array}{l}0.61 \\
1.01\end{array}$ & \\
\hline $\mathrm{U}$ & $\begin{array}{l}\mathrm{L} \\
\mathrm{L}\end{array}$ & $\begin{array}{l}b \\
c\end{array}$ & $\begin{array}{l}A^{*} \\
A^{*}\end{array}$ & $\begin{array}{l}\text { pi } \\
\text { cpi }\end{array}$ & $\begin{array}{l}\mathrm{h}^{*} \\
\mathrm{l}\end{array}$ & $\begin{array}{l}\mathrm{S} \\
\mathrm{S}\end{array}$ & $\begin{array}{l}0.48 \\
0.69\end{array}$ & \\
\hline
\end{tabular}

a: $\mathrm{Al}_{2} \mathrm{O}_{3}$ content of ore $(<1.3 \mathrm{wt} \% ; \mathrm{L},>2 \mathrm{wt} \% ; \mathrm{H}), b$ : inlet $a_{s}=0, c$ : inlet $a_{s}=1.28$, $d$ : external shape of ore (Fig. 13), oim: observed iron morphology, sfi: short fibrous iron, pi: porous iron, cpi: coarse porous iron, pli: plain iron, pci: plain coarse iron, $E_{\mathrm{si}}$ : surface energy of iron, h: high, l: low, S: sticking, F: fluidization, *: main causes for bed aspect

(5) Summation of Factors and Bed Aspect

Based on above statements, Fig. 14 illustrates that the bed aspect is affected by factors such as external shape of ore, iron morphology, surface energy of iron, and stirring force of bed, and how these factors are connected with initial conditions such as ore kind, reduction temperature, reducing gas, and inlet $a_{s}$, through inserting their derivative conditions such as $\mathrm{Al}_{2} \mathrm{O}_{3}$ content of ore, reducing potential, and $a_{s}$ in bed. Though the energy of cleaned iron surface might not almost depend on temperature, ${ }^{31,32)}$ appearance of iron whiskers tends to be predominated with increasing temperatures up to roughly $900^{\circ} \mathrm{C} .^{19-21)}$

For the reduction tests of 19 ores in G-B, Table 4 summarizes the above three factors, bed aspect ( $F$ : fluidization, S: sticking), and fractional reduction, which are influenced by conditions such as $\mathrm{Al}_{2} \mathrm{O}_{3}$ content of ore $(<1.3 \mathrm{wt} \% ; \mathrm{L},>2 \mathrm{wt} \% ; \mathrm{H})$ and $a_{s}$ in bed (inlet $a_{s}=0$ or 1.28). If the condition of either $\mathrm{Al}_{2} \mathrm{O}_{3}$ or $a_{s}$ is in a high level, the surface energy of iron $E_{\mathrm{si}}$ will become low (1) as a whole. The factors controlling especially the bed aspect are marked by superscript * as main causes, based on stated in this section. For the tests of ores $\mathrm{H}$ and I with inlet $a_{s}=0$ their values $E_{\mathrm{si}}$ may be low, because of high values $a_{s}$ in a bed caused by sulfur species existing in both original ores. ${ }^{8)}$ Ore $\mathrm{T}$ at inlet $a_{s}=0$ sticked despite of plain irons. This is probably owing to an active iron surface as an exception. Seven ores being typified by ore $\mathrm{B}$ which contain high $\mathrm{Al}_{2} \mathrm{O}_{3}$ above $2 \mathrm{wt} \%$ exhibited similar behavior concerning conditions, factors, and bed aspect.

Further researches are expected towards development 
of a stable fluidized bed reduction with higher proportions of metallic irons independently of ore kinds under a greater scale.

\section{Conclusions}

Seven types of iron ores were reduced in a fluidized bed using $\mathrm{N}_{2}-\mathrm{H}_{2}$ mixtures to investigate the sticking mechanism. The following results were obtained.

(1) Without $\mathrm{H}_{2} \mathrm{~S}$ addition, five types of ores poor in $\mathrm{Al}_{2} \mathrm{O}_{3}$ sticked soon after metallization accompanied with short iron whiskers and/or porous irons, while a couple of ores rich in $\mathrm{Al}_{2} \mathrm{O}_{3}$ showed no sticking with plain irons on their surface. In spite of an increase of reducing potential, the obtained surface microstructures were almost invariant compared with the above ones except enhancing their reduction levels.

(2) Though the addition of $\mathrm{H}_{2} \mathrm{~S}$ not able to form $\mathrm{FeS}$ into the gases did not much change the reduction behavior obtained in the case without sulfur addition, the introduction of $\mathrm{H}_{2} \mathrm{~S}$ enable to product $\mathrm{FeS}$ led to coarse surface morphologies along with their inactivation by sulfur, so that the bed could be fluidized until nearly complete reduction. This effect was slightly enhanced with a decrease of reducing potential.

(3) The chemical reaction rate of an ore bed with hydrogen during metallization process is fast enough so that the process should progress under the gas supply control, being accompanied with high gas utilizations above 0.9 .

(4) From the test results of 19 ores having a definite size, it was considered that for the condition fixing both temperature and reducing gas the fluidization behavior should be governed by factors such as iron morphology, surface energy of iron, and external shape of ore, and the first two factors are dependent upon the conditions such as $\mathrm{Al}_{2} \mathrm{O}_{3}$ content of ore, reducing potential, and sulfur activity in the bed. It was suggested that $\mathrm{Al}_{2} \mathrm{O}_{3}$ associated with the bed aspect exists near ore surface rather than that present in iron oxides.

\section{Acknowledgments}

The authors wish to thank Drs. S. Inaba, K. Sugiyama, and M. Deguchi, Kobe Steel, Ltd. for much supply of several types of ores and X-ray microanalysis of ores, and Dr. S. Sayama, Government Industrial Development Lab., Hokkaido for his kind support. Also, the experimental assistance of Mr. S. Sawai who is with Nippon Steel Corp., formerly a graduate student with Nagoya Institute of Technology is acknowledged.

\section{REFERENCES}

1) S. Kondo: Tetsu-to-Hagané, 60 (1974), 1542.

2) B. Cunningham and J. Stephenson: Direct Reduced Iron, Iron \& Steel Soc. of AIME, Warrendale, (1980), 64

3) A. Okura: Tetsu-to-Hagané, 57 (1971), S8.

4) S. Sayama, I. Sekiguchi and Y. Ueda: Tetsu-to-Hagané, 58 (1972), 240.

5) D. Neuschütz and T. Hoster: Steel Res., 60 (1989), 113.

6) K. Miyagawa, A. Kamijyo and M. Deguchi: CAMP-ISIJ, 2 (1989), 118.

7) S. Hayashi, S. Sayama and Y. Iguchi: ISIJ Int., 30 (1990), 722.

8) S. Hayashi and Y. Iguchi: Proc. of SRNC-90, Pohang, (1990), 166.

9) S. Y. Ezz: Trans. Met. Soc. AIME, 218 (1960), 709.

10) B. G. Langston and F. M. Stephens, Jr.: J. Met., 12 (1960), 312.

I1) J. F. Gransden, J. S. Sheasby and M. A. Bergougnou: Chem. Eng. Prog. Symp. Ser., 66 (1970), 208.

12) J. F. Gransden and J. S. Sheasby: Can. Metall. Q., 13 (1974), 649.

13) R. Watanabe, K. Shinohara, T. Ashinaga, M. Onoda and K. Mori: Tetsu-to-Hagané, 72 (1986), 1279.

14) D. Neuschütz: Proc. of SRNC-90, Pohang, (1990), 176.

15) K. Kunitomo and Y. Hayashi: CAMP-ISIJ, 1 (1988), 1129.

16) H. Katayama, H. Itaya, S. Taguchi, K. Kimura, T. Kanetsuna, I. Kobayashi and M. Matsui: CAMP-ISIJ, 4 (1991), 31.

17) R. B. Smith and M. J. Corbett: Ironmaking Steelmaking, 14 (1987), 49.

18) R. J. Fruehan: Proc. of SRNC-90, Pohang, (1990), 39.

19) S. Hayashi, Y. Iguchi and J. Hirao: Tetsu-to-Hagané, 71 (1985), 1311.

20) S. Hayashi, Y. Iguchi and J. Hirao: Tetsu-to-Hagané, 73 (1987), 1668.

21) S. Hayashi and Y. Iguchi: ISIJ Int., 29 (1989), 642.

22) D. Kunii and O. Levenspiel: Fluidization Engineering, John Wiley \& Sons Inc., New York, (1969), 73.

23) S. Hayashi and Y. Iguchi: Tetsu-to-Hagané, 74 (1988), 656.

24) L. von Bogdandy and H. J. Engell: The Reduction of Iron Ores, Springer Verlag, Berlin, (1971), 38.

25) R. Nicolle and A. Rist: Metall. Trans. B, 10B (1979), 429.

26) S. Hayashi and Y. Iguchi: ISIJ Int., 29 (1989), 596.

27) S. Hayashi, Y. Iguchi and J. Hirao: Tetsu-to-Hagané, 71 (1985), 672.

28) I. Barin, M. Modigell and F. Sauert: Metall. Trans. B, 18B (1987), 347.

29) Y. Iguchi, M. Iida and M. Inoue: Tetsu-to-Hagané, 65 (1979), 24

30) W. D. Kingery, H. K. Bowen and D. R. Uhlmann: Introduction to Ceramics, John Wiley \& Sons Inc., New York, (1975), 183.

31) H. J. Grabke, E. M. Petersen and S. R. Srinivasan: Surf. Sci., 67 (1977), 501

32) E. D. Hondros: Acta Metall., 16 (1968), 1377. 